\title{
Characterization and Immobilization of Peroxidase Extracted from Horse Radish and Decolorization of Some Dyes
}

\author{
Ali J.R. AL-Sa'ady ${ }^{1}$, Maha Hameed A. Al-Bahrani ${ }^{2 *}$ and Ghazi M. Aziz ${ }^{1}$ \\ ${ }^{1}$ Department of Biotechnology, College of Science, University of Baghdad, Iraq \\ ${ }^{2}$ Molecular and Medical Biotechnology Dept. College of Biotechnology, \\ University of Al-Nahrain, Iraq \\ *Corresponding author
}

\begin{tabular}{|l|}
\hline K ey w or d s \\
Peroxidase, Horseradish, \\
Immobilization, \\
Optimization, \\
Decolorization
\end{tabular}

\section{A B S T R A C T}

The present work was undertaken to obtain crude Peroxidase extract from radish to characterize it in terms of $\mathrm{pH}$, temperature, number of times use and decolrization of some dyes. The results shows that peroxidase from radish gave highest specific activity 4391 $\mathrm{U} / \mathrm{mg}$, and potassium phosphate buffer $(0.1 \mathrm{M}, \mathrm{pH} 7)$ was best extraction buffer for peroxidase extraction from radish with specific activity $4489 \mathrm{U} / \mathrm{mg}$, while The highest specific activity was measured for crude extract at $1: 2$ ratio, it was $4479 \mathrm{U} / \mathrm{mg}$ protein. Entrapment of peroxidase enzyme by agarose was best method for immobilization. The optimum $\mathrm{pH}$ of free and immobilized peroxidase enzyme activity was 6.0 , while the $\mathrm{pH}$ stability of free peroxidase enzyme from radish was 6.0 , and the $\mathrm{pH}$ stability of immobilized peroxidase enzyme was range from 4.0-8.0. The optimum temperature for free peroxidase activity from radish was $35{ }^{\circ} \mathrm{C}$, while the free enzyme was stable in temperature $35-60{ }^{\circ} \mathrm{C}$, then the activity begun to decrease and was completely lost in 65 $70^{\circ} \mathrm{C}$. The best temperature for immobilized peroxidase activity was $35^{\circ} \mathrm{C}$, while the results showed that the immobilized enzyme was stable in temperatures between $35-45^{\circ} \mathrm{C}$. The activity of the immobilized enzyme which incubated many times with substrate was decreased after eighth time using. Giemsa stain and acridine orange, were removed and make change in their absorbance after incubation with immobilized eighth enzyme for period of time, while no degradation of the other dyes occur.

\section{Introduction}

Peroxidase enzymes (donor: $\mathrm{H}_{2} \mathrm{O}_{2}$ oxidoreductase, Ec. 1. 1 1.1.7 are widely distributed in plants, animal tissue and microorganisms. Peroxidase was first found in the fig tree in 1936. In 1941 the enzyme was isolated and characterized from horseradish (HRP) (Andrew et al., 2013). During the years of 1942 to 1959 , isolation of the enzyme was reported from various sources such as yeast, potato, beans, Japanese radish and wheat.

Peroxidase enzyme is widely found in the nature, their diversity can be seen in the plant kingdom and within the same plant species also became as an indicator of genetic discrimination in many plants to detection of stress in plants as well as follow-up and study the mechanism of the effect of pathogens on 
plant families (Cheung and Tai, 2007). Peroxidases became important industrially and medically, peroxidase were gained (hours radish peroxidase HRP) great economic importance through its uses in the number of diagnostic and analytical varied because of his qualities kinetic and physical and chemical suitable for such applications and perhaps the most important number is the number of ELISA (Enzyme - Linked Immuno Sorbent Assay) in labeling antibodies or antigens in the immune reactions by attaching these enzymes on solid surfaces as it is the specifications that qualify for that one of these properties the qualities high affinity toward the material basis (Yazdi et al., 2002), ease of detection effectiveness configures outputs of color, do not need a process to measure the steps separating from substrates, high persistence during storage, low costs for preparation and purification as well as its importance in the analysis of the stigma blot assays and in pigmentation tissue it is also used in biochemical analysis to estimate the hydrogen peroxide generated by some systems, such as the oxidation of glucose, amino acids and cholesterol ... etc. (Passardi et al., 2007). Also reflected the importance of these enzymes in the processing of fruits and vegetables by evaluating the content extracts of food stuff from antioxidants such as ascorbic acid, phenols, flavonoids and tannins, which working on multiple modifications during the manufacturing process and storage (Fatima et al., 2007). Enzyme immobilization can endow enzymes with some additional advantageous properties. The immobilized enzymes can be used repeatedly or continuously in a variety of reactors for the efficient recovery of costly enzymes, and be easily separated from reaction systems for reuse, which make the work-up simple and the protein of the final product uncontaminated. Furthermore, it is reported that immobilized enzymes may exhibit higher selectivity and specificity (Kiralp et al., 2003).

\section{Materials and Methods}

\section{Chemical materials}

Guaiacol, phosphate buffer, Tris- $\mathrm{HCl}$, Coomassie brilliant blue, bovine serum albumin were obtained from Sigma Co. other chemicals were supplied by BDH Chemicals.

\section{Peroxidase source}

Different sources were used for extraction of peroxidase. These sources were radish, cabbage, potato, green onion top, white onion, green onion leaves, white bean, apricot seeds, red bean, and soybean. All sources were washed with tab water then extraction of the enzyme. The enzyme activity and concentration of peroxidase were determination.

\section{Determination of peroxidase activity}

The activity of peroxidase is measured according to Silva and Koblitz (2010). The substrate solution was prepared by mixing the following volumes according to each ratio, guaiacol: Hydrogen peroxide solution: Sodium acetate solution: Distilled water [1: 1: 1: 7 (v: $\mathrm{v}: \mathrm{v}: \mathrm{v})]$. The reaction solution contained 2.9 $\mathrm{mL}$ of substrate solution $(\mathrm{pH} 6.0)$ and $0.1 \mathrm{ml}$ of the enzyme. $3 \mathrm{~mL}$ of substrate solution was used as blank sample.

The oxidation of guaiacol was detected by measuring the absorbance increase at $470 \mathrm{~nm}$ after 3 min using a spectrophotometer. One unit of peroxidase activity was defined as the amount of enzyme that caused an increase in absorbance of $0.001 / \mathrm{min}$. Calculation of peroxidase activity was used the following equation:

Activity of peroxidase $\left(\mathrm{U} \cdot \mathrm{ml}^{-1}\right)=[(\mathrm{A} 2$ sample - A1 sample) - (A2 blank - A1 blank)]/ $(0.001 \times \mathrm{t})$ 
A2 sample: is the final absorbance of the sample, A1sample: is the initial absorbance of the sample; A2 blank: is the final absorbance of the control, A1 blank: is the initial absorbance of the control, and $t$ is the reaction time in minutes ( 3 minutes).

\section{Protein concentration determination}

Protein concentration was determined according to the dye-binding method of Bradford using bovine serum albumin as a standard (Bradford, 1976).

\section{Type of extraction buffer}

Radish was homogenized with different types of buffers for peroxidase extraction.

These buffers are sodium acetate at concentration $0.1 \mathrm{M}$ at $\mathrm{pH} 5.0$ and 6.0 , sodium citrate $0.1 \mathrm{M}$ at $\mathrm{pH} 4.0$, potassium phosphate $0.1 \mathrm{M}$ at $\mathrm{pH} 7.0$ and Tris- $\mathrm{HCl} 0.1 \mathrm{M}$ at $\mathrm{pH} 8.0$., also used water tap and distilled water for extraction of peroxidase enzyme from the radish. The activity and concentration estimated in each treatment (Silva and Koblitz, 2010).

\section{Extraction ratio}

A twenty five grams of radish were homogenized in different volumes of buffer extract (0.1 M phosphate buffer $\mathrm{pH}$ 7.0) for extraction of peroxidase enzyme. The extraction ratios were 1:0.5, 1:0.75, 1:1, 1:1.5, 1:2, 1:3 and 1:4 (v:w). The enzyme activity and protein concentration was then determined.

\section{Immobilization of peroxidase}

\section{Entrapment by agarose}

The entrapment on agarose done by dissolved $3 \mathrm{~g}$ from agarose in $100 \mathrm{ml}$ distil water under heat condition then cooling and mixing with peroxidase in volume $1: 0.25(\mathrm{v} / \mathrm{v})$ then pour it in plate until solid and cut it a square pieces $(2 \times 2 \mathrm{~cm})$ and store in sodium acetate buffer (0.02M pH 6.0).

The activity of the immobilized enzyme was calculated (Kiralp et al., 2003).

\section{Entrapment by Ca-alginate}

It was prepared by dissolving $5 \mathrm{~g}$ of $\mathrm{Na}-$ alginate in $100 \mathrm{ml}$ distilled water under heat condition then cooling it and mixing it with peroxidase in volume $1: 0.25(\mathrm{v} / \mathrm{v})$ then add the mixture as drop by syringe in $2 \mathrm{M} \mathrm{CaCl}_{2}$ solution, then beads was washed with $0.02 \mathrm{M}$ sodium acetate buffer (2M, pH 6.0).

The activity of the immobilized enzyme was calculated, then the remaining activity $\%$ was measured (Duran et al., 2002).

\section{Characterization of free and immobilized enzyme}

\section{The effect of pH on enzyme activity}

Different types of buffer were used $(1 \mathrm{M}$ sodium acetate $\mathrm{pH}$ range between 3 to $6,0.1 \mathrm{M}$ phosphate buffer $\mathrm{pH} 7$, and $0.1 \mathrm{M}$ Tris- $\mathrm{HCl}$ $\mathrm{pH} 8$ and 9) in the preparation of reacting substrate then we incubate free and immobilized enzyme with substrate and measure the activity (Mizobutsi et al., 2010).

\section{The effect of pH on enzyme stability}

Different types of buffer $(0.1 \mathrm{M}$ sodium acetate $\mathrm{pH} 3-6,0.1 \mathrm{M}$ phosphate buffer $\mathrm{pH} 7.0$ and $0.1 \mathrm{M}$ Tris- $\mathrm{HCl} \mathrm{pH} 8-9\}$ were prepared to incubate with the free and immobilized enzyme at a ratio (1:1 v:v) for $30 \mathrm{~min}$., then the remaining activity $\%$ for each enzyme was calculated (Saeidian, 2013). 
The effect of temperature on enzyme activity

The free and immobilized enzyme were incubated with substrate for $3 \mathrm{~min}$ in a water bath at different temperature $(35,40,45,50$, $55,60,65$ and $70^{\circ} \mathrm{C}$ ), then the activity was measured for each temperature (Mizobutsi et al., 2010).

The effect of temperature on enzyme stability

One $\mathrm{ml}$ and $1 \mathrm{gm}$ from free and immobilized enzyme respectively were incubated in water bath at different temperature $(35,40,45,50$, $55,60,65$ and $70{ }^{\circ} \mathrm{C}$ ) for 30 min then transfer it directly to cold water and the remaining activity $\%$ was measured for each temperature (Saeidian, 2013).

The effect of number of times for using the immobilized enzyme

The experiment of number of times for using the immobilized enzyme was done by weighting $1 \mathrm{gm}$ from immobilized enzyme and incubate with substrate then the enzyme activity was measured, then the immobilized enzyme was washed with $0.1 \mathrm{M}$ potassium phosphate buffer ( $\mathrm{pH}$ 7) and repeated incubation of enzyme with new substrate and measure enzyme activity then the activity was repeated for many time, until less the enzyme activity to calculate the number of times for using the immobilized enzyme (Guisan, 2014).

\section{Decolorization of some dyes by immobilized peroxidase enzyme}

Stock solutions of 7 type of dyes (brilliant green, bromophenol blue, Giemsa stain, toluidine blue, neutral red, acridine orange and indigo carmine) were prepared in sterilized distilled water and diluted to $25 \mathrm{mg} / \mathrm{L}$. The optical density of each dye was measured depending on its $\lambda$-max using a spectrophotometer. The reaction mixture was prepared by adding $1 \mathrm{gm}$ of immobilized peroxidase enzyme to $3 \mathrm{ml}$ of the dye solution, then measure the change of absorbance for each dye depend on their $\lambda$-max. A control sample was prepared for each dye without immobilized enzyme and treated under the same condition. Decolorization efficiency of immobilized peroxidase was assessed by monitoring the decrease in absorbance under maximum wavelength of the dye (Guisan, 2014).

\section{Results and Discussion}

\section{Effect different sources on peroxidase activity}

Different specific peroxidase activities were shown for various plant sources as in figure 1. This figure shows that peroxidase from radish gave highest specific activity $4391 \mathrm{U} / \mathrm{mg}$, while cabbage, potato, green onion top, green onion leaves, soybean and red bean were $1796,140,255,455,8$ and $21 \mathrm{U} / \mathrm{mg}$, respectively. White onion, white bean, and apricot seeds didn't give any activity. Radish was used as a source of peroxidase because it's available, and inexpensive.

A study by (Sariri et al., 2003), was illustrated that the specific activity of peroxidase extracted from soybean seed coat was $37.7 \mathrm{U} / \mathrm{mg}$ protein. Other study by (Rudrappa et al., 2005), was shown the specific peroxidase activity from hairy root cultures of red beet was $600 \mathrm{U} / \mathrm{mg}$ proteins.

\section{Type of extraction buffer}

The specific peroxidase activity was estimated after extraction the enzyme with different buffer, as shown in figure 2 . These results show that potassium phosphate buffer $(0.1 \mathrm{M}$, 
pH 7) was best extraction buffer with specific activity reached to $4489 \mathrm{U} / \mathrm{mg}$, while other buffers were given low specific activity.

$\mathrm{pH}$ effect on enzymatic activity and stability can be explain by the fact that depending on influence the structure of enzyme by changing the $\mathrm{pH}$ degree that may lead to differences ionization state of the various amino acid residues (Mizobutsi et al., 2010). The effect of $\mathrm{pH}$ on peroxidase activity was shown in several ways. First, each enzyme has its own optimum $\mathrm{pH}$, for maximum enzyme activity, but the enzyme is stable within certain limits under and above the optimum $\mathrm{pH}$ thus any changing in the degree of $\mathrm{pH}$ lead to denature the enzyme structure. Third, any change in the $\mathrm{pH}$ may cause dissociate of substrate-enzyme complex (Guisan, 2014). (Harco et al., 1999) were shown the optimum $\mathrm{pH}$ value for extraction of peroxidase from Nicotiana tabacum by potassium phosphate buffer $50 \mathrm{mM}$ was $\mathrm{pH}=7.5$ adding to its $1 \mathrm{mM}$ Corbett, DTT, EDAT and 3\% Triton X-100 and $0.8 \mathrm{M} \mathrm{NaCl}$ in extraction ratio $1: 4(\mathrm{w}: \mathrm{v})$.

\section{Entrapment by agarose}

After the preparation of immobilized enzyme by agarose and cutting it to squares, the activity of immobilization enzyme was 153 $\mathrm{U} / \mathrm{gm}$, and the amount of the enzyme which immobilized in this process was $64 \%$.

\section{Entrapment by Ca-alginate}

Entrapment of peroxidase enzyme by $\mathrm{Ca}$ alginate was the best immobilized enzyme method. It was shown that immobilized peroxidase activity was $109 \mathrm{U} / \mathrm{gm}$. The entrapment method is based on the occlusion of an enzyme within a polymeric network that allows both substrate and product to pass through the polymer but retains the enzyme. This method differs from the other coupling methods, in that the enzyme is not bound to the matrix or membrane. There are different approaches to entrap enzymes such as gel or fiber entrapping and microencapsulation (Kiralp et al., 2003).

\section{The optimum ratio of peroxidase extraction}

Seven ratios were chosen $(1: 0.5,1: 0.75,1: 1$, $1: 1.5,1: 2,1: 3$ and $1: 4(\mathrm{v}: \mathrm{w})$ to determine the best ratio for peroxidase extraction by using potassium phosphate $0.1 \mathrm{M}(\mathrm{pH}=7.0)$. The highest specific activity was measured for crude extract at 1:2 ratio, it was $4479 \mathrm{U} / \mathrm{mg}$ protein, while other ratio were 1:0.5, 1:0.75, $1: 1,1: 1.5,1: 3$ and $1: 4$ gave the following specific activities 2183, 2526, 2227, 294, 2950 and $3315 \mathrm{U} / \mathrm{mg}$ protein respectively (Figure 3). Nidadavolu et al., (2010) were found that the best extraction ratio for peroxidase from discarded mushroom beds was 1:1 and 1:2. While (Tsujimura et al., 1994), shown the best ratio was 1:5 for peroxidase extraction from Arthromyces ramosus.s

\section{Immobilization of peroxidase}

\section{Enzyme characterization}

\section{Determination of the optimum $\mathrm{pH}$ of free peroxidase activity}

The effect of $\mathrm{pH}$ on peroxidase activity was studied. The results showed that the $\mathrm{pH} 6.0$ is the optimum $\mathrm{pH}$ for peroxidase activity, while the activity decreased in $\mathrm{pH}$ below and above 6.0 .

Figure 4 shows the effect of different $\mathrm{pH}$ on free enzyme activity. Mader et al., (1977) found that the optimum $\mathrm{pH}$ of peroxidase from Tobacco leaves was 5.5- 6.0, while (Padiglia et al., 1995), pointed to the maximum activity of peroxidase from Rice seedlings was in the $\mathrm{pH}$ equal to 5.7, also the optimum $\mathrm{pH}$ for peroxidase purified from strawberry fruits was 6.0 (Civello et al., 1995). 
Fig.1 Effect different sources on peroxidase activity

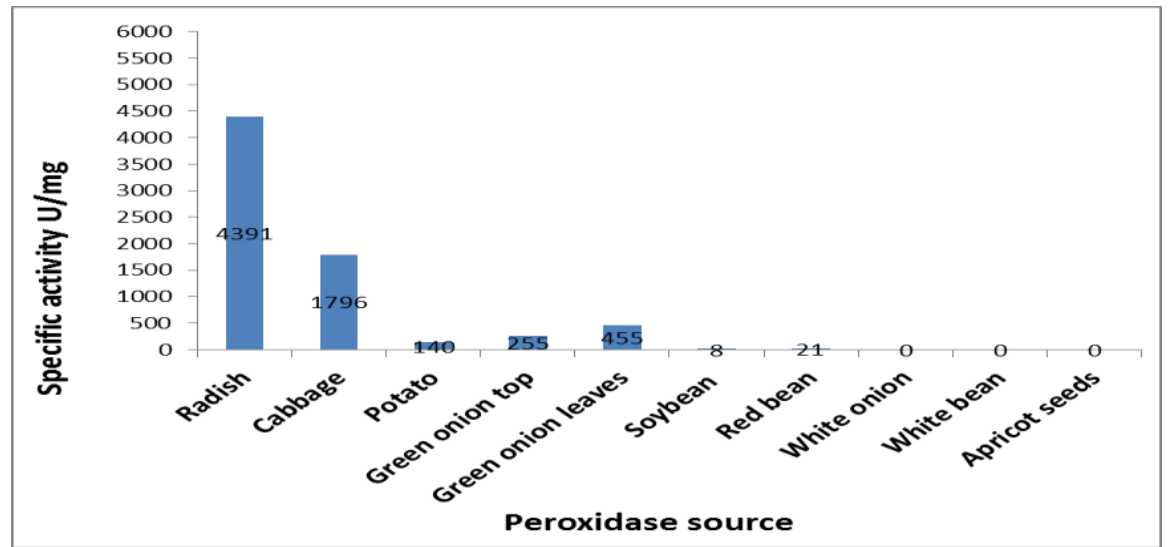

Fig.2 The effect the type of extraction buffer for peroxidase extraction from the radish

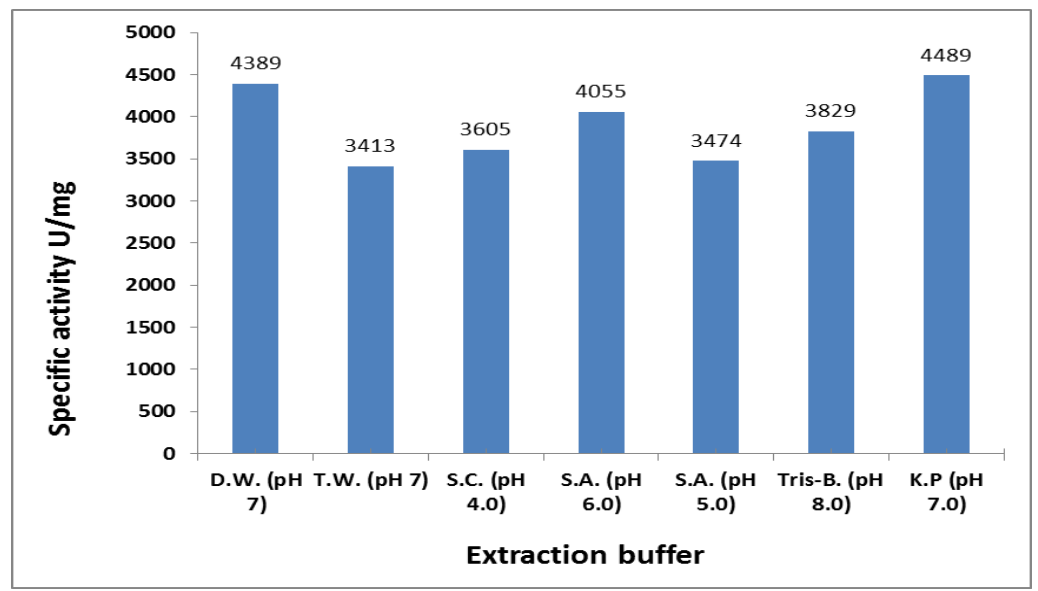

S.A. $=$ Sodium acetate, Tris-B. $=$ Tris-base, K.P. $=$ Potassium phosphate, S.C. $=$ Sodium citrate, D.W. $=$ Distilled water, T.W. = Tap water.

Fig.3 The effect of extraction ratio on peroxidase extraction from radish

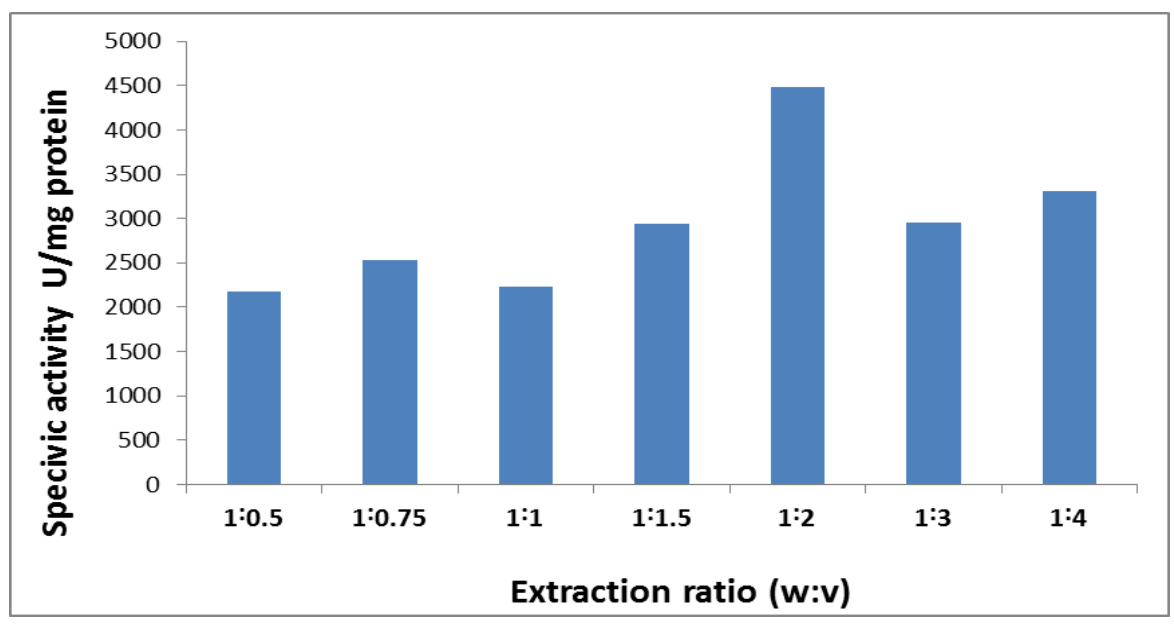


Fig.4 Optimum $\mathrm{pH}$ for free peroxidase activity from the radish

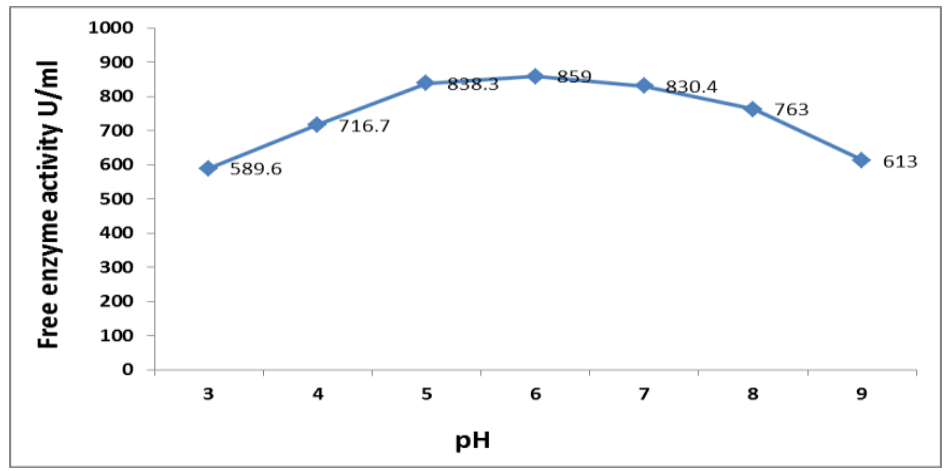

Fig.5 Effect of $\mathrm{pH}$ on the stability of free peroxidase from radish

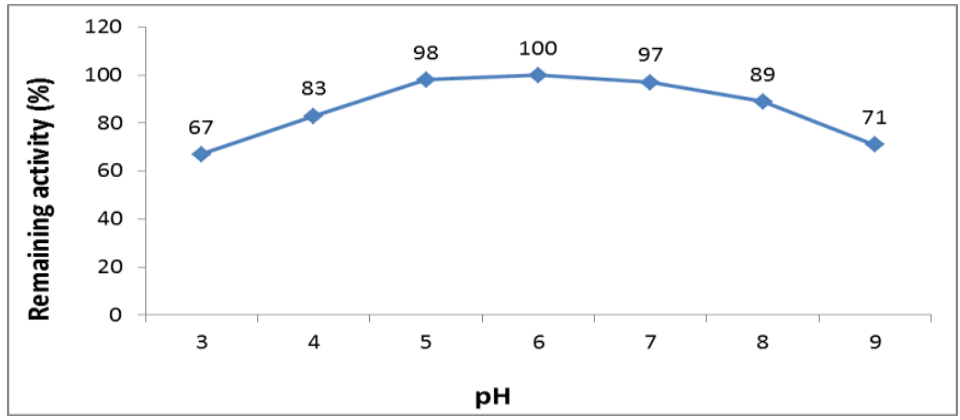

Fig.6 Optimum pH for immobilized peroxidase activity from radish

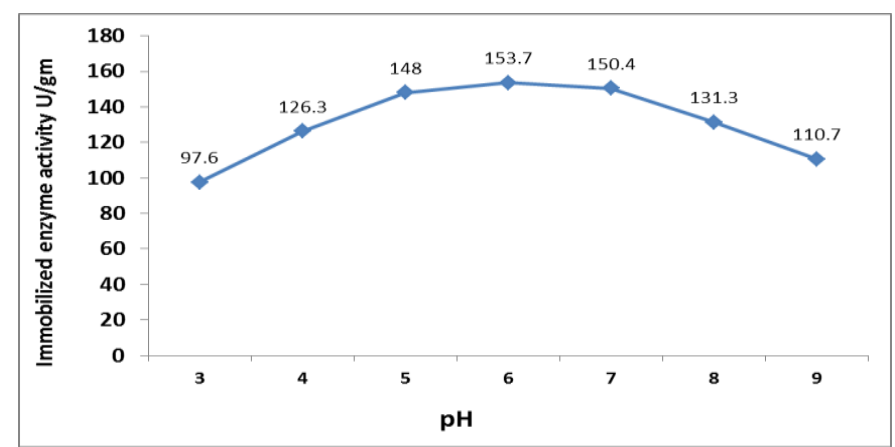

Fig.7 Effect of $\mathrm{pH}$ on the stability of immobilized peroxidase enzyme from the radish

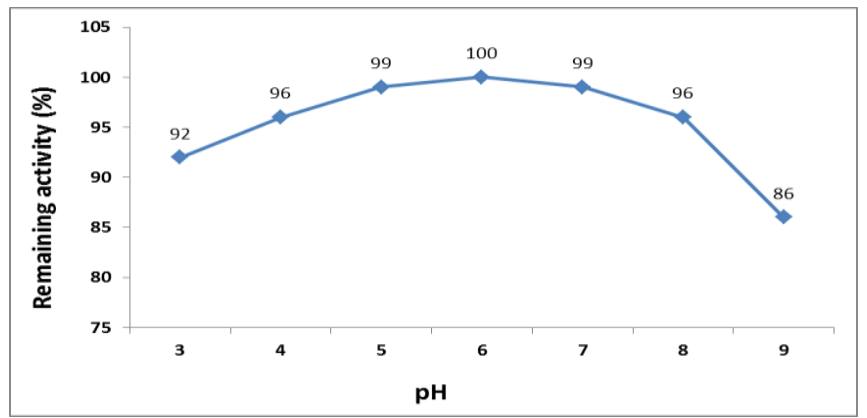


Fig.8 Optimum temperature for free peroxidase activity from the radish

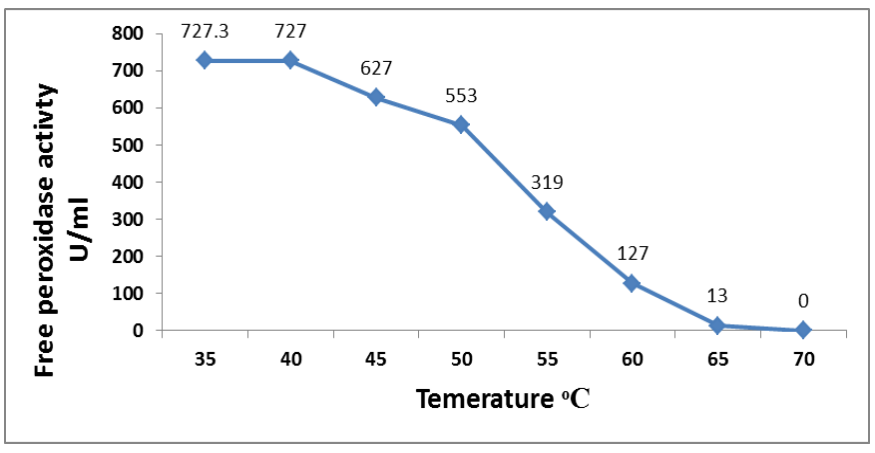

Fig.9 Thermal stability of free peroxidase from the radish

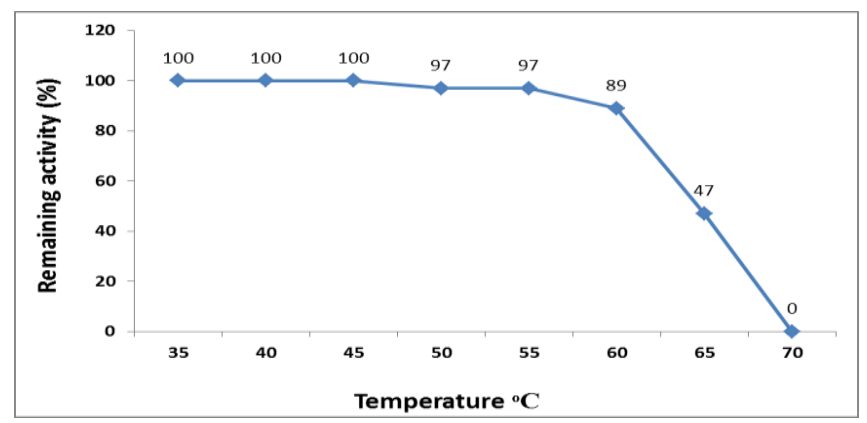

Fig.10 Optimum temperature for immobilized peroxidase activity from the radish

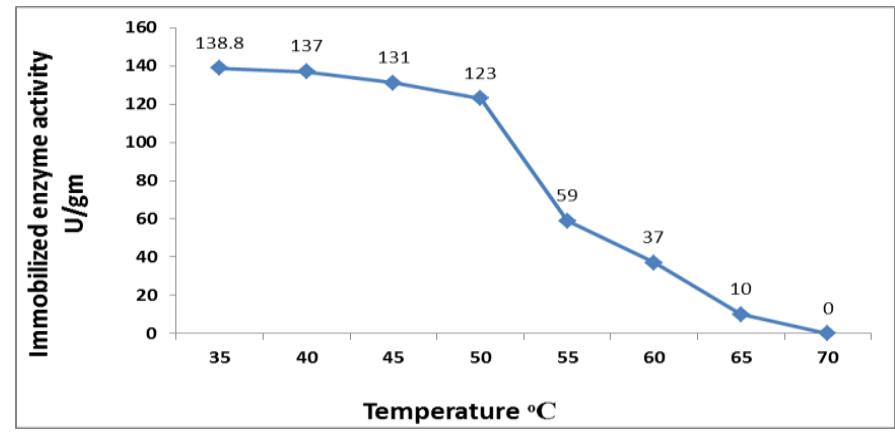

Fig.11 Thermal stability of immobilized peroxidase from the radish

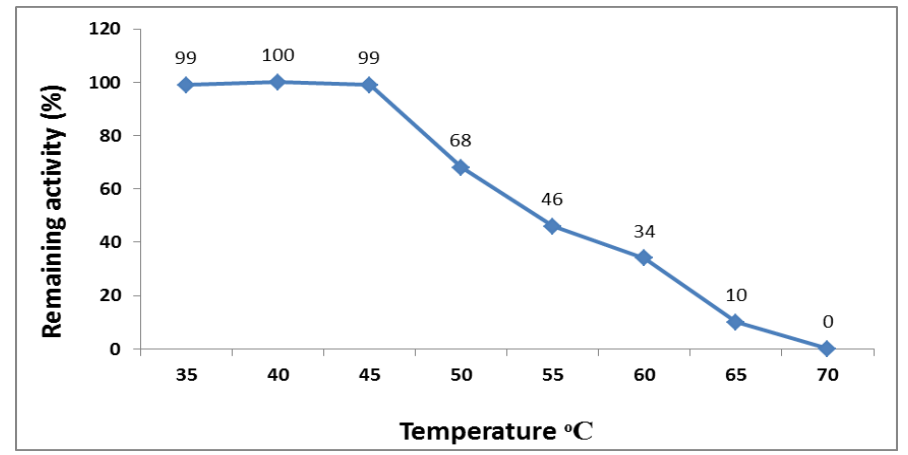


Fig.12 Number of times for using the immobilized peroxidase from the radish

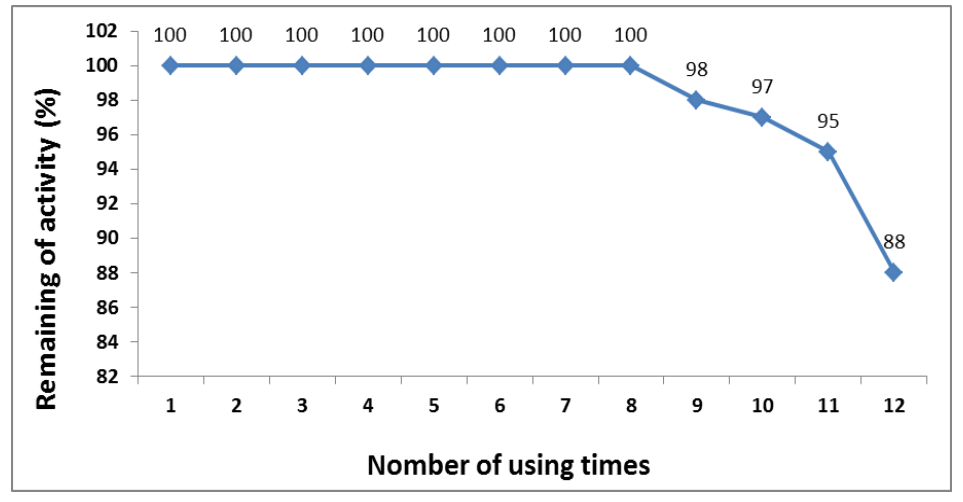

Table.1 Decolorization of some dyes by immobilized peroxidase enzyme

\begin{tabular}{|c|c|c|c|c|c|c|c|c|c|c|c|}
\hline Time & $\begin{array}{c}\bar{\Lambda}- \\
\max \\
(\mathrm{nm})\end{array}$ & $\begin{array}{c}\text { Ab.at } \\
\text { zero time } \\
\text { (nm) }\end{array}$ & $\begin{array}{c}3 \\
\min \end{array}$ & $\stackrel{6}{\min }$ & $\begin{array}{c}9 \\
\min \end{array}$ & $\begin{array}{c}12 \\
\min \end{array}$ & $\begin{array}{c}15 \\
\mathrm{~min}\end{array}$ & $\begin{array}{c}18 \\
\min \end{array}$ & $\begin{array}{c}21 \\
\mathrm{~min}\end{array}$ & $\begin{array}{c}24 \\
\mathrm{~min}\end{array}$ & $\begin{array}{c}27 \\
\mathrm{~min}\end{array}$ \\
\hline $\begin{array}{l}\text { Brilliant } \\
\text { green }\end{array}$ & 628 & 0.262 & 0.262 & 0.262 & 0.262 & 0.262 & 0.262 & 0.262 & 0.262 & 0.262 & 0.262 \\
\hline $\begin{array}{l}\text { Bromophenol } \\
\text { blue }\end{array}$ & 590 & 1.817 & 1.817 & 1.817 & 1.817 & 1.817 & 1.817 & 1.817 & 1.817 & 1.817 & 1.817 \\
\hline Giemsa stain & 520 & 0.164 & 0.142 & 0.134 & 0.121 & 0.117 & 0.101 & 0.092 & 0.073 & 0.073 & 0.073 \\
\hline $\begin{array}{l}\text { Toluidine } \\
\text { blue }\end{array}$ & 626 & 1.542 & 1.542 & 1.542 & 1.542 & 1.542 & 1.542 & 1.542 & 1.542 & 1.542 & 1.542 \\
\hline Neutral red & 540 & 1.47 & 1.587 & 1.468 & 1.231 & 1.162 & 1.034 & 0.872 & 0.691 & 0.627 & 0.573 \\
\hline $\begin{array}{l}\text { Acridine } \\
\text { orange }\end{array}$ & 490 & 0.347 & 0.319 & 0.239 & 0.111 & 0.096 & 0.073 & 0.058 & 0.041 & 0.054 & 0.067 \\
\hline $\begin{array}{l}\text { Indigo } \\
\text { carmin }\end{array}$ & 490 & 0.896 & 0.896 & 0.896 & 0.896 & 0.896 & 0.896 & 0.896 & 0.896 & 0.896 & 0.896 \\
\hline
\end{tabular}

Determination of $\mathrm{pH}$ for free peroxidase stability

The $\mathrm{pH}$ of enzyme stability was studied because it is an important criteria in determining the optimum conditions for purification and enzyme storage. The results (Figure 5) were demonstrated $o$ the range of peroxidase stability was from $4.0-8.0$, while the activity was low at 3.0 and 9. $\mathrm{pH}$ values. The lowering in enzymatic activity in extreme acidic and extreme basic conditions may be due to changes in secondary and tertiary structure of the enzymatic residues as well as changes in ionic state of the active site of the enzyme
(Lehmacher and Bisswanger, 1990). (Yoon et al., 2003), showed that the optimum $\mathrm{pH}$ of peroxidase stability from Helianthus tuberosus ranging between 5.0 and 6.0, while (Silva and Valdir, 2000), found that the optimum $\mathrm{pH}$ of peroxidase purified from papaya fruits ranging between 6.0 and 9.0 when incubation the enzyme with buffer at $\mathrm{pH} 3.0$.

Determination of the optimum $\mathrm{pH}$ for immobilized peroxidase activity

The effect of $\mathrm{pH}$ on immobilized peroxidase activity was studied; figure 6 shows results that the $\mathrm{pH} 6.0$ is the optimum $\mathrm{pH}$ for peroxidase 
activity, while the activity decreased in $\mathrm{pH}$ below and above 6.0. The $\mathrm{pH}$ of a solution can have several effects on the structure and activity of enzymes; $\mathrm{pH}$ can have an effect on the state of ionization of acidic or basic amino acids. Acidic amino acids have carboxyl functional groups in their side chains, basic amino acids have amine functional groups in their side chains. If the state of ionization of amino acids in a protein is altered then the ionic bonds that help to determine the 3-D shape of the protein can be altered. This can lead to altered protein recognition or an enzyme might become inactive. Changes in $\mathrm{pH}$ may not only affect the shape of an enzyme but it may also change the shape or the properties of the substrate so that either the substrate cannot bind to the active site or it cannot undergo catalysis (Chesworth et al., 1998).

\section{Determination of $\mathrm{pH}$ for immobilized peroxidase stability}

The $\mathrm{pH}$ of immobilized enzyme stability was studied because it is an important criterion in determining the optimum conditions for the storage of the immobilized enzyme. Figure 7 shows the results of the study, where the range of immobilized peroxidase stability was from 4.0 - 8.0, while the activity was very low at acidic $\mathrm{pH}$ (below 3) and basic $\mathrm{pH}$ at 9 conditions. The lowering in enzymatic activity in low extreme acidic and extreme basic conditions may be due to changes in the secondary and tertiary structure of the enzymatic residues as well as changes in the ionic state of the active site of the enzyme and substrate (Lehmacher and Bisswanger, 1990). The $\mathrm{pH}$ of the environment of an enzyme may affect the activity of the enzyme in several ways. First, each enzyme has its $\mathrm{pH}$ optimum, at which the enzyme is most active, but the enzyme is stable within certain limits on each side of the optimum. Secondly, the environmental $\mathrm{pH}$ of the enzyme may influence its stability, and at extremes of acidity or alkalinity the enzyme may be denatured. Thirdly, the $\mathrm{pH}$ of the reaction mixture may cause dissociation of the substrate and so by its action on the substrate influence the character of the $\mathrm{pH}$ activity curve and the $\mathrm{pH}$ optimum. These factors have been discussed by (Moat et al., 2002).

\section{Optimum temperature of free peroxidase activity}

Optimum temperature of free peroxidase activity was studied by incubating the enzyme with the substrate at different temperatures 35$70{ }^{\circ} \mathrm{C}$ for $3 \mathrm{~min}$., the results showed that the optimum temperature for free peroxidase activity from radish was $35^{\circ} \mathrm{C}$, where it gave the highest activity at this temperature 727.3 $\mathrm{U} / \mathrm{ml}$ (Figure 8), and the activity decreases higher than this temperature and lost completely at $65^{\circ} \mathrm{C}$.

\section{Thermal stability of free peroxidase enzyme}

Incubation of peroxidase from radish in different temperature degrees between $35-70$ ${ }^{\circ} \mathrm{C}$ for $30 \mathrm{~min}$, showed that the enzyme was stable in temperature $35-60{ }^{\circ} \mathrm{C}$, then the activity began to decrease and was completely lost in $65-70^{\circ} \mathrm{C}$ (Figure 9). This decrease in enzymatic activity may be due to the thermal effect on the enzyme structure then its denaturation. Where temperature may effect on the protein structure by breaking the bonds that stabilize the secondary and tertiary structure of the protein which results to denaturation (Chesworth et al., 1998).

\section{Optimum temperature of immobilized peroxidase activity}

Optimum temperature of immobilized peroxidase activity was studied by incubating the enzyme with the substrate at different temperatures $35-70{ }^{\circ} \mathrm{C}$ for $3 \mathrm{~min}$., the results showed that the best temperature for immobilized peroxidase activity from radish was $35^{\circ} \mathrm{C}$, with activity $138.8 \mathrm{U} / \mathrm{gm}$ (Figure $10)$, and the activity decreases above than this temperature and lost completely at 65 and 70 ${ }^{\circ} \mathrm{C}$. 


\section{Thermal stability of immobilized peroxidase}

The stability of horse radish peroxidase was measured after incubated the enzyme for $30 \mathrm{~min}$ at temperature degrees range of $35-45^{\circ} \mathrm{C}$, and the results show that the activity of enzyme began to decrease at $55^{\circ} \mathrm{C}$ and was completely lost at $70^{\circ} \mathrm{C}$ (Figure 11).

\section{Number of times for using the immobilized peroxidase}

The results of reuse immobilized enzyme with its substrate show that the activity of immobilized enzyme decrease after 12 time as in figure 12.

Whereas a study by Gar and Glu (2002), demonstrated that the activity of immobilized peroxidase from quince decrease after four times.

\section{Dye decolorization}

The immobilized peroxidase was used for the decolorization several types of dyes in order to demonstrate their ability in treatment of waste water .

The results show that only two dyes (Giemsa stain and Acridine orange) were reduced and make changes in their absorbance, while no degradation of the other dyes occurs as shown in the table 1 .

The optimum $\mathrm{pH}$ of free and immobilized peroxidase enzyme activity was 6.0. The stability $\mathrm{pH}$ for free and immobilized peroxidase enzyme isolated from radish was 4.8 and 3.9 respectively.

The immobilized peroxidase had the ability to decolorization some dyes such as Giemsa stain and acridine orange.

\section{References}

Andrew, J., Price, F., and Norsworthy, G.K. (2013). Cover Crops for Weed
Management in Southern ReducedTillage Vegetable Cropping Systems. Weed Technology. 27(1): 212-217.

Bradford, M. (1976). A rapid and sensitive method for the quantitation of microgram quantities of protein using the principle of protein-dye binding. Anal. Biochem., 72: 248-254.

Chesworth, J. M., Stuchbury, T., and Scaif, J. R. (1998). An Introduction to agricultural biochemistry. Chapman \& Hall, London. 5(2): 215-223.

Cheung, S and Tai, J. (2007). Anti- proliferative and antioxidant properties of rosemary Rosemarinus officinalis. Oncol Rep17: 152-161.

Civello, P.M., Martinez, G.A., Chaves, A.R., and Anon, M.C. (1995). Peroxidase from strawberry fruit; partial purification and determination of some properties. J. Agri. Food chem., 43: 2596- 2601.

Duran, N., Rosa, M.A., Annibale, A.D., and Gianfreda, L. (2002). Application of laccases and tyrosinases (phenol oxidases) immobilized on different supports: a review, Enzyme and Microbial Technology. 31:907-931.

Fatima, A., Husain, Q., and Hasan Khanb, R. (2007). "A peroxidase from bitter gourd (Momordica charantia) with organic solvent and detergent: A comparison enhanced stability against with horseradish peroxidise," J. Mol. Catal. B: Enzymatic. 47, 66.

Gar, H.Y.K. and Glu, A.S. (2002). NonCovalent Immobilization of Quince (Cydonia oblonga) peroxidase. Turk $\mathrm{J}$ Chem. 26:751-758.

Guisan, J. M. (2014). Immobilization of enzymes and cells. 2nd ed. Madrid, Spain.

Harco, A.S., Jon, K.L., and Lorenzo, F.P. (1999). Isolated and purification peroxidase from Nicotiana tabacum. J. Biochim., 23: 567-569.

Kiralp, S., Toppare, L., and Yagci, Y., (2003). Immobilization of polyphenol oxidase in conducting copolymers and determination of phenolic compounds in wines with 
enzyme electrodes. International Journal of Biological Macromolecules, 33:37-41.

Lehmacher, A. and Bisswanger, H. (1990). Isolation and characterization of an extremely thermostable D-glucose/ Xylose isomerase from ThermusaquaticusHB8. J Gen Microbiol. 136: 679-686.

Mader, M., Nessel, A., and Bopp. (1977). Plant Enzyme. Plant physiol. 82: 247.

Mizobutsi, G. P., Finger, F. L., Ribeiro, R. A., Puschmann, R., Neves, L. D. M., and Mota, W. F. D. (2010). Effect of $\mathrm{pH}$ and temperature on peroxidase and polyphenoloxidase activities of litchi pericarp. J. Sci. Agric. 67(2): 213-217.

Moat, A. G., Foster, J. W. and Spector, M. P. (2002). Microbial Physiology. $4^{\text {th }}$ ed. Wiley-Liss, Inc., New York. 1: 1-28.

Nidadavolu, H. B., Metuku, R.P., Burra, S., and Pyram, R. (2010). Bioactive compounds from discarded mushroom beds. Turk $J$. Biol. 36: 275-284

Padigila, A., Medda, R., and Cruciani, E. (1995). Fractionation and Characterization of two form of peroxidase from Oryza sativa. Preparative Biochemistry. 25(1\&2): 1119.

Passardi, F., Bakalovic, N., Teixeira, F.K., Margis-Pinheiro, M., Penel, C., and Dunand, C. (2007). Prokaryotic origins of the non-animal peroxidase superfamily and organellemediated transmission to eukaryotes. Genomics. 89:567-579.

Rudrappa, T., Neelwarne, B., Kumar, V., Lakshmanan, V., Venkataramareddy, S.R., and Aswathanarayana, R.G. (2005). Peroxidase production from hairy root cultures of red beet (Beta vulgaris).
Electronic Journal of Biotechnology. 8(2): 185- 196

Saeidian, S. (2013). Partial purification and characterisation of polyphenol oxidase from tomatoes (Solanum lycopersicum). International journal of Advanced Biological and Biomedical Research. 1(6): 637-648.

Sariri, R., Najafi, F., and Rezazadeh, A.R. (2003). Soybean seed coat contains higher peroxidase than other parts of plant. Int. J. Chem. Sci. 1(2): 79-82.

Silva and Valdir. (2000). Soluble and Bound peroxidase from papaya fruit Phytochemistry. 29(4): 1051-1056.

Silva, C. R. D., and Koblitz, M. G. B. (2010). Partial characterization and inactivation of peroxidases and polyphenol-oxidases of um-bu-cajá (Spondias spp.). Cienc. Technol. Ali-ment., Campinas. 30(3): 790-796.

Tsujimura, H., Takaja, M., Katano, K., Matsumoto, N., Park, Y. S., and Okabe, M. (1994). Peroxidase production by carbon and nitrogen sources feed-batch culture of Arthromyces ramosus. Biotechnol. Lett. 16:575-580.

Yazdi, M., Tabatabaie; Khaleghparast, Sh. and Monsef, H.R. (2002). Purification and some partial characterization of peroxidase isoenzyme from Brassica oleraceacapitata L. Journal of Sciences, 13(2): 107-112.

Yoon, E. S., Kang, S-J., Noh, B-S., and Choi, E-H. (2003). Isolation and characterization of peroxidase from Jerusalem artichoke tubers. J. food sci. technol. 25(5): 565-570.

\section{How to cite this article:}

Ali J.R. AL-Sa'ady, Maha Hameed A. Al-Bahrani and Ghazi M. Aziz. 2018. Characterization and Immobilization of Peroxidase Extracted from Horse Radish and Decolorization of Some Dyes. Int.J.Curr.Microbiol.App.Sci. 7(06): 328-339. doi: https://doi.org/10.20546/ijcmas.2018.706.037 